Article

\title{
Basic Study of Ventilation Using Semi-Transparent Organic Photovoltaic Sheets for Solar Chimney Systems
}

\author{
Kishio Hidaka ${ }^{1, *}$, Akari Miyazawa ${ }^{2}$, Hong Hu ${ }^{2}$, Kazuya Mitsuji ${ }^{1}$, Yasuo Nagai ${ }^{1}$, \\ Naoki Yoshimoto ${ }^{3}$ and Yuko Suenaga 4 \\ 1 Department of Architecture, Design \& Building Science, Graduate School of Science and Engineering, \\ Yamagata University, 1-4-12 Kojirakawa, Yamagata-shi, Yamagata 990-8640, Japan; \\ mitu@e.yamagata-u.ac.jp (K.M.); y-nagai@e.yamagata-u.ac.jp (Y.N.) \\ 2 Student of Faculty of Education, Art and Science, Yamagata University, 1-4-12 Kojirakawa, Yamagata-shi, \\ Yamagata 990-8640, Japan; e157024@st.yamagata-u.ac.jp (A.M.); e157012@st.yamagata-u.ac.jp (H.H.) \\ 3 Center for Exploratory Research, Research \& Development Group, Hitachi, Ltd., 14-433, 7-3-1 Hongo, \\ Bunkyo-Ku, Tokyo 113-8656, Japan; naoki.yoshimoto.rr@hitachi.com \\ 4 Sato Kogyo, 1-10-3 Honcho, Aoba-ku, Sendai-Shi, Miyagi 980-0014, Japan; Y.Suenaga@satokogyo.co.jp \\ * Correspondence: hidaka-3130025@e.yamagata-u.ac.jp; Tel.: +81-23-628-4348
}

Received: 19 July 2018; Accepted: 28 September 2018; Published: 9 October 2018

\begin{abstract}
An energy-efficient building ventilation system is presented that integrates semitransparent organic photovoltaic (OPV) technology and solar chimney technology. It achieved a wind velocity of $0.25 \mathrm{~m} / \mathrm{s}$ and electric power generation of about $1.03 \mathrm{~W}$ at an artificial light intensity of $320 \mathrm{~W} / \mathrm{m}^{2}$, which corresponds to cloudy weather. These results support the basic study of systems combining ventilation and power generation. The integration of solar chimney ventilation with OPV power generation could be a promising system for energy savings in the future. The proposed integration could contribute to the generation of sustainable and renewable energy.
\end{abstract}

Keywords: organic photovoltaic sheet; OPV; solar chimney

\section{Introduction}

The Sustainable Development Goals (SDGs) established by the United Nations in 2015 were confirmed as a guiding principle for achieving a better future for everyone in the world. Although the Goals appear to be independent, they are actually interrelated. For example, sustainable energy cannot be considered separately from renewable energy. Distributed electric power systems are promising candidates for sustainable and renewable energy generation, such as solar photovoltaic systems [1-3]. The implementation of photovoltaic systems in urban areas is particularly challenging due to space limitations and the lack of direct sunlight. Building integrated photovoltaic (BIPV) systems are being used to overcome these limitations. They integrate the photovoltaic system into building walls, therefore, they make efficient use of limited spaces [4-6]. As BIPV panels have an absorption efficiency of over $95 \%$, they make efficient use of indirect sunlight. One drawback to their use is the waste heat, which can increase the thermal load in a building. Thermal loads are already increasing due to the ongoing trend of expanding the window areas of buildings (which can exceed $50 \%$ of the total area). These increasing thermal loads can be effectively managed by implementing intelligent window systems [7-11], which combine window shading with thermal insulation or other intelligent functions for building management.

A typical intelligent window system is the double-skin windows $[7,8,12-14]$, which consists of two sheets of solar shading glass such as a low-e glass and thermal absorption glass. Heat ventilation 
occurs as outlet air passing through the cavity between the two skins. In this way, the waste heat created by the BIPV panels is purged. Another application of double-skin windows is solar chimney ventilation $[10,11,15,16]$ to naturally vent exhaust waste heat. When semi-transparent photovoltaic panels are used instead of solar power shading glass [17-19], double-skin windows and solar chimney ventilation can be used for not only building thermal management but also for harvesting solar energy.

There are two types of semi-transparent photovoltaic panels, the dye-sensitized type and the amorphous silicon. Yoon et al. [20] evaluated the dye-sensitized type by simulating their energy-saving performance. Olivieri et al. [21] reported that semi-transparent amorphous silicon photovoltaic panels could be superior to glass windows in terms of the solar heat gain coefficient and heat loss ratio. Peng et al. [22] demonstrated the experimental usage of semi-transparent amorphous silicon photovoltaic sheets applied to double-skin façades in Hong Kong. They reported a reduction in the heat load due to their use in combination with a passive ventilation system. Tan and Wong [23] obtained sufficient wind velocity, $2.0 \mathrm{~m} / \mathrm{s}$ at a light intensity of $700 \mathrm{~W} / \mathrm{m}^{2}$, from roof-top solar chimneys in Singapore. Lee et al. [24] studied the feasibility of dye-sensitized solar cells for building window systems. They relied on the local weather for the parameters of their simulation. Dye-sensitized solar cells will be promising energy devices if their cost penalty is eliminated.

Transparency is one of the most important requirements for intelligent window systems. Organic photovoltaics (OPV) is a promising technology for high transparency window systems. In both the materials and devices fields, the use of OPV has resulted in high transparency and the development of many color variations for heat-absorbing glass. The use of narrow bandgap donor materials in OPV devices has resulted in the production of more non-visible (colorless) windows [25]. Fabrication technologies such as the nano-wired metallic back electrode [26] may be applicable to not only transparent OPV devices but also various optical properties such as plasmonic optical response. Recently, simulation approaches with an OPV window system to be demonstrate in architectural fields. Kapsis and Athienitis [27] predicted the potential benefits of applying semi-transparent photovoltaics to commercial buildings. They simulated the electricity consumption of a building in which OPV panels were installed. Although there has been much progress in the applications of OPV panels, their application has only been simulated.

The application of a semi-transparent OPV panel to an intelligent window system was previously demonstrated $[28,29]$ such as a back grounds. We have now investigated a system integrating an OPV panel and a solar chimney. The feasibility of this new approach of using a solar chimney ventilation system with an embedded semi-transparent OPV panel was evaluated experimentally using a prototype. Solar chimneys are widely used for sustainable environmental management as they contribute to zero energy consumption and environmental friendliness. OPV panels are thus promising candidates for an additional power generation.

\section{Materials and Methods}

A small-scale model was manufactured for evaluating the compatibility of ventilation and power generation, as shown in Figure 1. An OPV device was installed on the solar chimney surface. Foam polystyrene was used for the outer structure of the chimney as a thermal insulation material. A polycarbonate plate was used as a transparent material on the inner surface of the chimney. The device was partially glued under the polycarbonate plate. The model was exposed to light from a solar spectrum light source (ES01-297, EKO) (Figure 2). Light intensities of $255 \mathrm{~W} / \mathrm{m}^{2}, 350 \mathrm{~W} / \mathrm{m}^{2}$, $450 \mathrm{~W} / \mathrm{m}^{2}, 655 \mathrm{~W} / \mathrm{m}^{2}$, and $780 \mathrm{~W} / \mathrm{m}^{2}$ were used.

The OPV device was obtained from Konarka Technologies whose specifications are listed elsewhere. The stacking sequence of the device is shown in Figure 3. Energy conversion efficiency ranged from $1 \%$ to $1.6 \%$ depending on the temperature. 


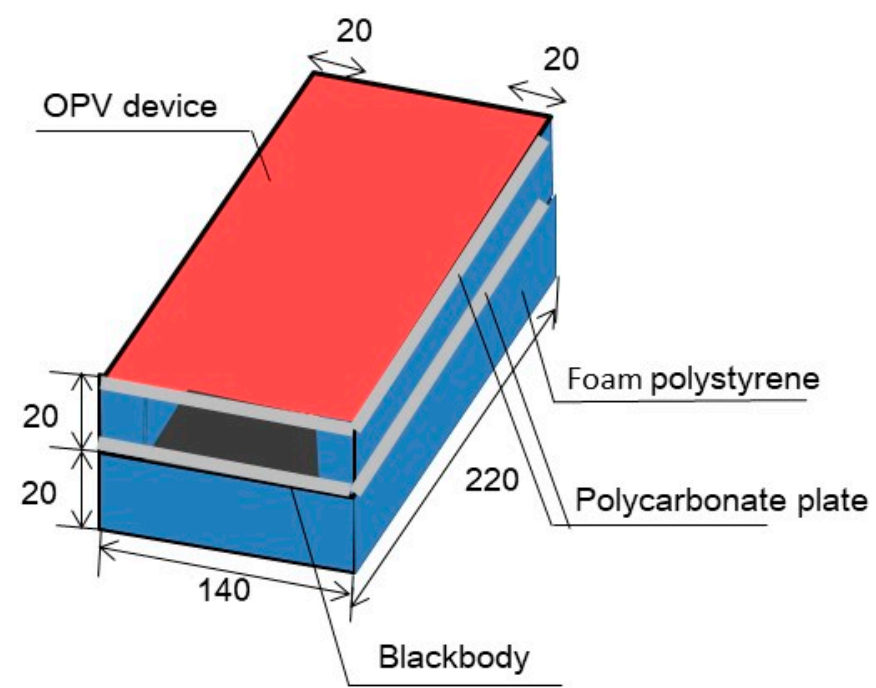

Figure 1. Projection drawing of small-scale OPV-solar chimney model (Unit: mm).

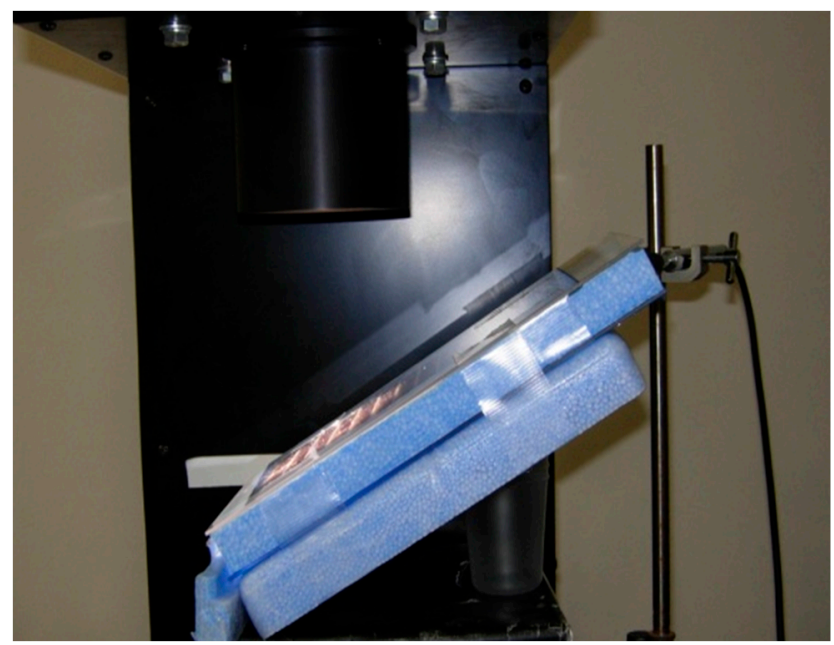

Figure 2. Exposure of OPV-solar chimney to solar spectrum light source.

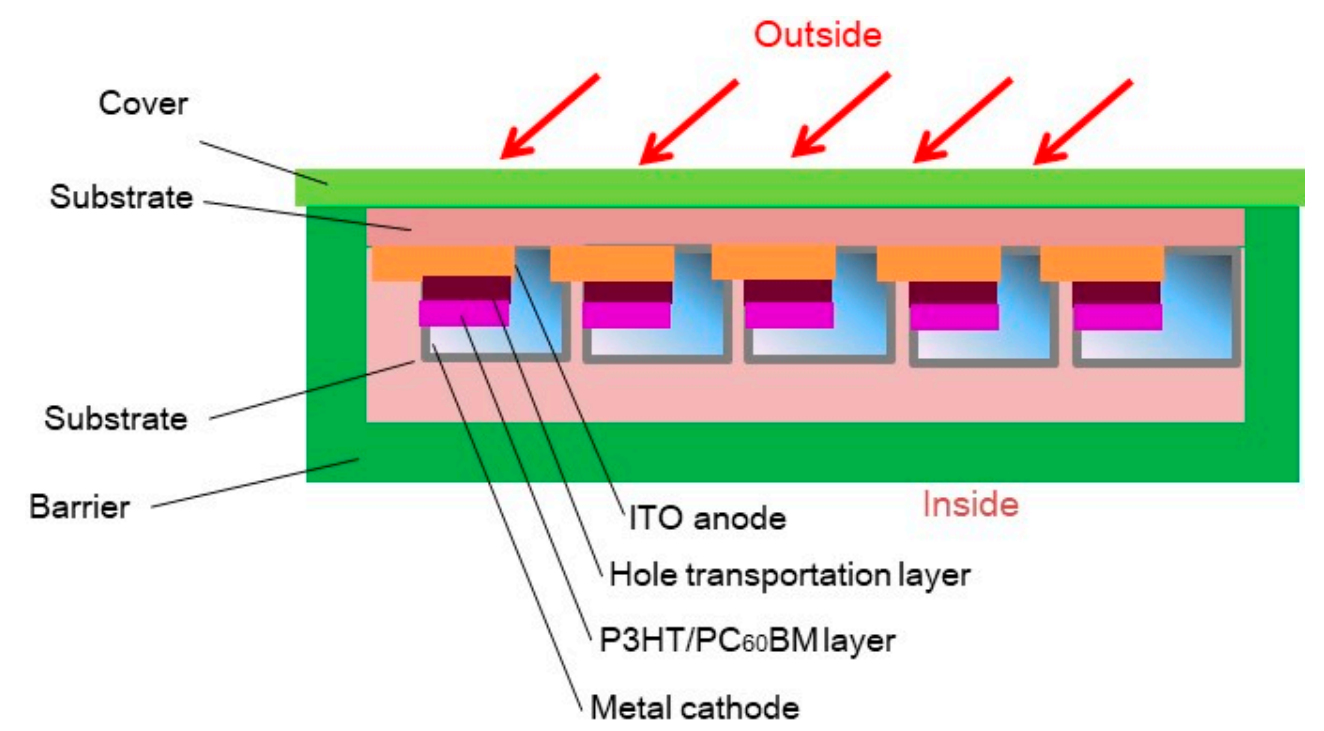

Figure 3. Drawing of transverse section of OPV device showing stacking structure. 
The intensities of light for various simulated weather conditions are listed in Table 1. A zero-degree pitch angle is defined as the OPV plane relative to the incident beam. The pitch angle of the OPV-solar chimney was set to $10^{\circ}, 30^{\circ}$, or $45^{\circ}$.

Table 1. Simulated weather as a function of solar intensity.

\begin{tabular}{cc}
\hline Intensity of Light $\left(\mathbf{W} / \mathbf{m}^{2}\right)$ & Simulated Weather \\
\hline 255 & Rain \\
350 & Cloudy \\
450 & Partly sunny in winter \\
655 & Sunny in winter, partly sunny in summer \\
780 & Sunny in summer \\
\hline
\end{tabular}

Figure 4 shows the set-up position of the anemometer and thermocouples. A hot-wire anemometer (Custom WS-03SD) was used to measure wind velocity. K type thermocouples were used to measure the temperature. The data was acquired out using a 12-channel temperature recorder (Lutron BTM-4208SD).

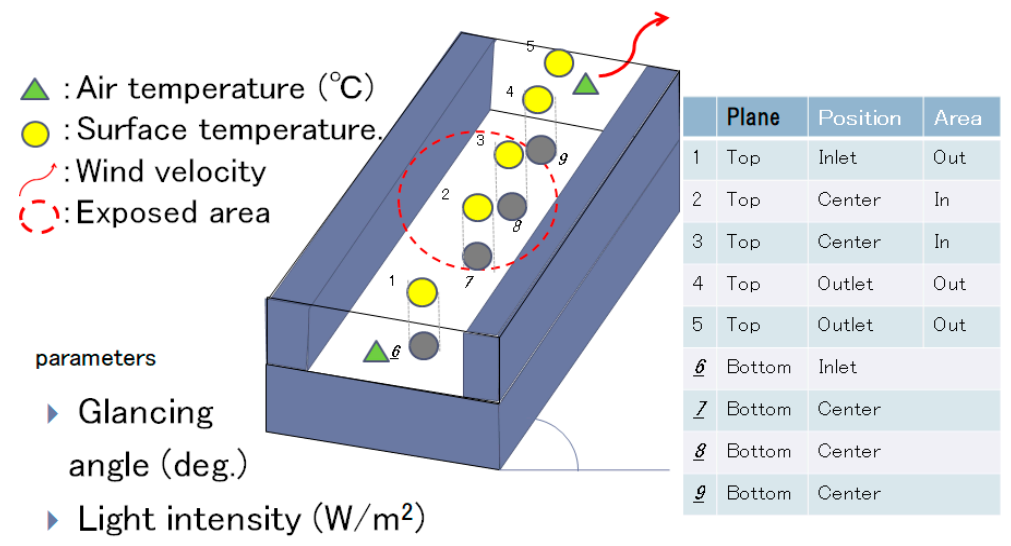

Figure 4. Set-up drawing of small-scale OPV-solar chimney model (Unit: mm).

Figure 5 shows an experimental view of a large-scale OPV-solar chimney model. The outer dimensions were $1400 \mathrm{~mm}$ long, $700 \mathrm{~mm}$ wide, and $100 \mathrm{~mm}$ high. The gap between the top and bottom of cavity was $30 \mathrm{~mm}$. Air flow was visualized by smoke. A solar light was used to irradiate the OPV-solar chimney. The wavelength of the light (500 W capacity, SOLAX XC-500EF) was varied from 350 to $2500 \mathrm{~nm}$ in $12,600 \mathrm{~cd}$ under irradiation.

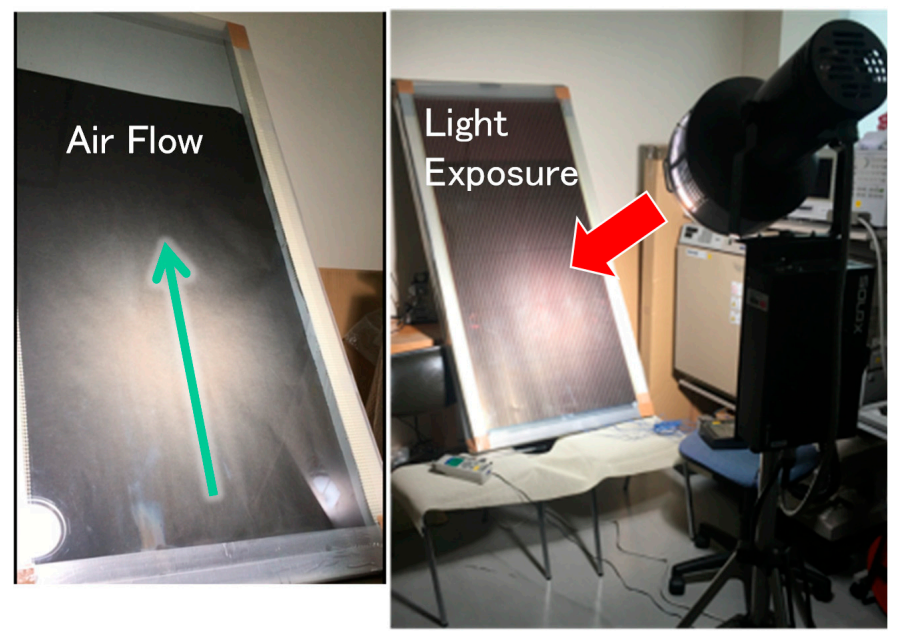

Figure 5. Experimental view of large-scale OPV-solar chimney model. 


\section{Results and Discussion}

The thermal shading effect is an important concern for the OPV-solar chimney because a substantial increase in temperature around the perimeter zone in a house during summer is a crucial issue for the environmental friendliness of architectures and buildings.

Figure 6 shows the reflectance of a full-size OPV sheet as a function of wavelength. These results were used to evaluate heat transmittance and the heat gain coefficient. They were $5.91 \mathrm{~W} / \mathrm{m}^{2} \mathrm{~K}$ and 0.34 , respectively.

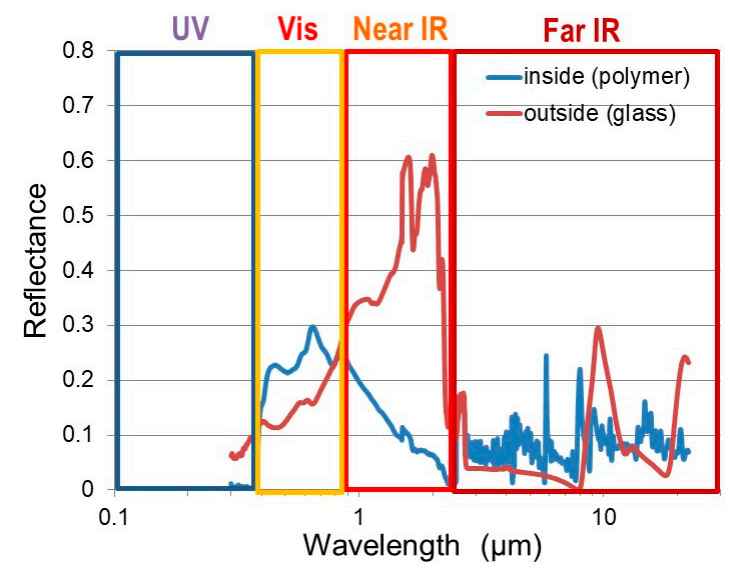

Figure 6. Reflectance of full-size OPV sheet as a function of wavelength as calculated using Japanese Industrial Standards R 3106 and A 5759.

Figure 7 shows the power generation performance of an OPV sheet as a function of temperature for a large-scale solar chimney. Although crystalline photovoltaics degrade energy conversion efficiency as the temperature increases, the efficiency increased as the temperature increased with the OPV sheet. This is an advantage of OPV from the architectural point of view.
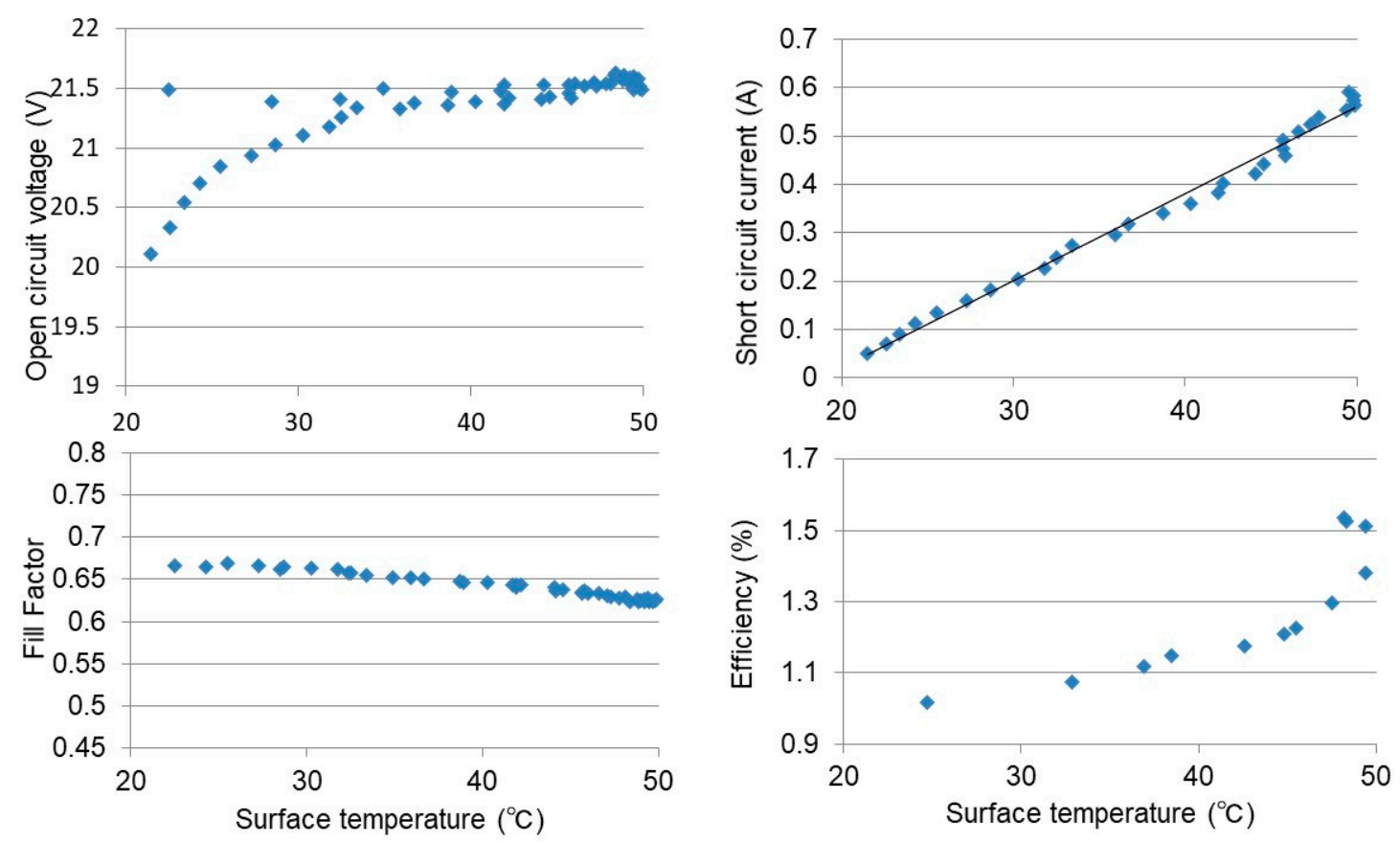

Figure 7. Power generation performance of OPV sheet as a function of temperature for large-scale solar chimney. 
The thermal shading effect of an OPV sheet was demonstrated by measuring the perimeter thermal load and the surface temperature of an OPV sheet. The sheet was applied to single-glazed glass in a commercial building in Ibaraki prefecture, Japan [28]. The perimeter thermal load was estimated by measuring the globe temperature, which indicates the thermal radiation in the perimeter zone with sunlight.

The solar power absorption of an OPV sheet was determined by measuring the temperature of the sheet's surface. Figure 8 shows the thermal profile during $24 \mathrm{~h}$ in winter, reflecting the thermal shading effect. The surface temperature of the OPV sheet ((b) in Figure 8) increased as the sun rose, reaching a maximum when the sun's inclination angle exceeded $50^{\circ}$. In contrast, that of a single-glazed glass((c) in Figure 8) remained below $30^{\circ}$ even during the day. This difference of more than $20^{\circ}$ can serve as the driving force of the updraft in a solar chimney.

In our solar chimney demonstration, the backside materials were urethane foam insulation with a black coating. This means that solar light passing through a semi-transparent OPV sheet might be absorbed by the backside wall and converted into updraft thermal energy. A double-skin façade can be constructed by applying OPV film to single-glazed glass. Such a solar chimney system would exhibit not only natural ventilation but also a thermal insulation effect. In fact, the globe temperature in the OPV perimeter zone ((d) in Figure 8) was dramatically lower, evidence of a thermal insulating effect in this solar chimney system.

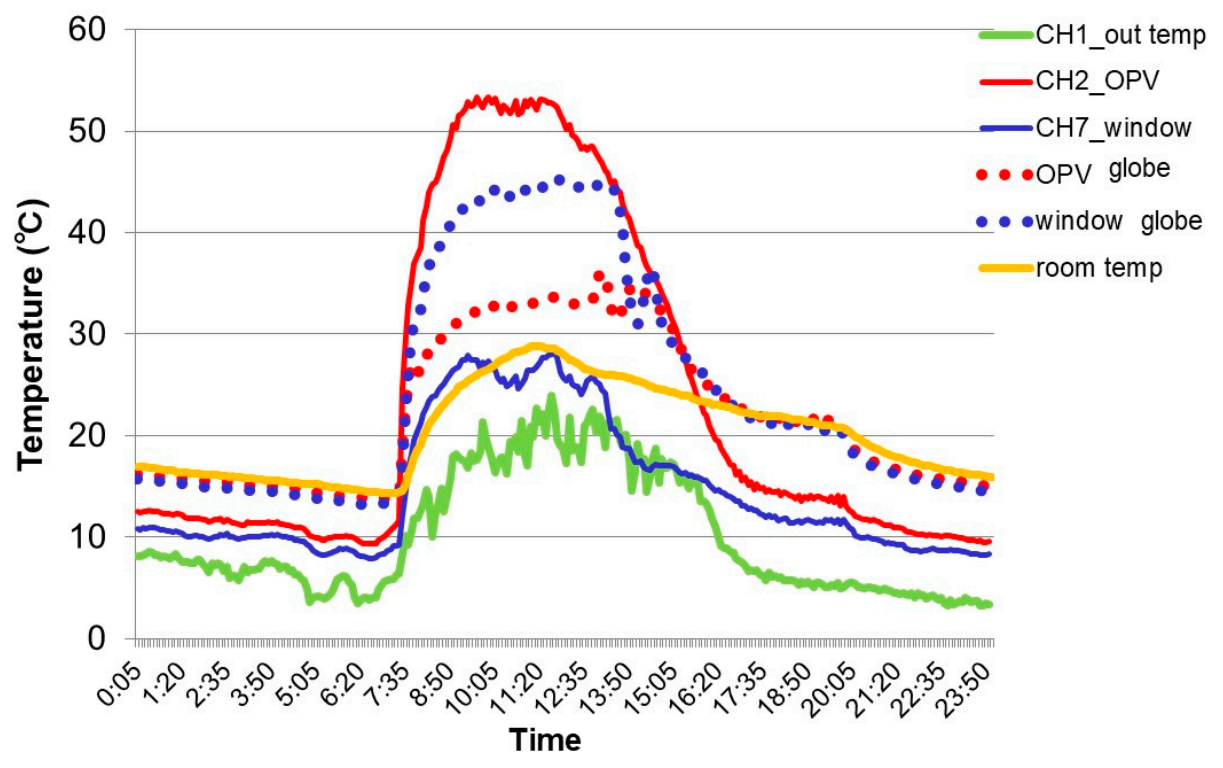

Figure 8. Thermal profile during $24 \mathrm{~h}$ in winter.

If the transparency of the OPV is not sufficient to enable sunlight to warm the solar chimney, the chimney will not be able to generate wind. The results plotted in Figure 9 show that the application of an OPV sheet does not interfere with wind generation. These results shown that the OPV-solar chimney concept can be implemented in new ventilation systems.

Figure 10 shows the inlet and outlet temperatures of the chimney as a function of the light intensity. The inlet temperature profile displays a plateau while the outlet temperature profile increases. The wind velocity can be determined from Bernoulli's principle:

$$
\frac{1}{2} v^{2}+\omega+g z=\text { constant }
$$


where $v$ is fluid velocity, $\omega$ is enthalpy, $g$ is gravity, and $z$ is height. The $\omega$ can be written as $\omega=T d s+V d p$, where $T$ is temperature, $s$ is entropy, $V$ is volume, and $p$ is pressure. The $\omega$ may vanish for ideal gas since an isentropic process occurs. In that case, Equation (1) can be expressed as

$$
v=\mathrm{Cd} \sqrt{2 g \operatorname{Lsin} \theta\left(T_{\text {out }}-T_{\text {in }}\right) / T_{\text {out }}}
$$

where $v$ is the velocity of the generated wind, $\mathrm{Cd}$ is the discharge coefficient, $g$ is gravity, $L$ is the longitudinal length of the chimney, $\theta$ is the pitch angle, $T_{\text {out }}$ is the outlet temperature, and $T_{\text {in }}$ is the inlet temperature.

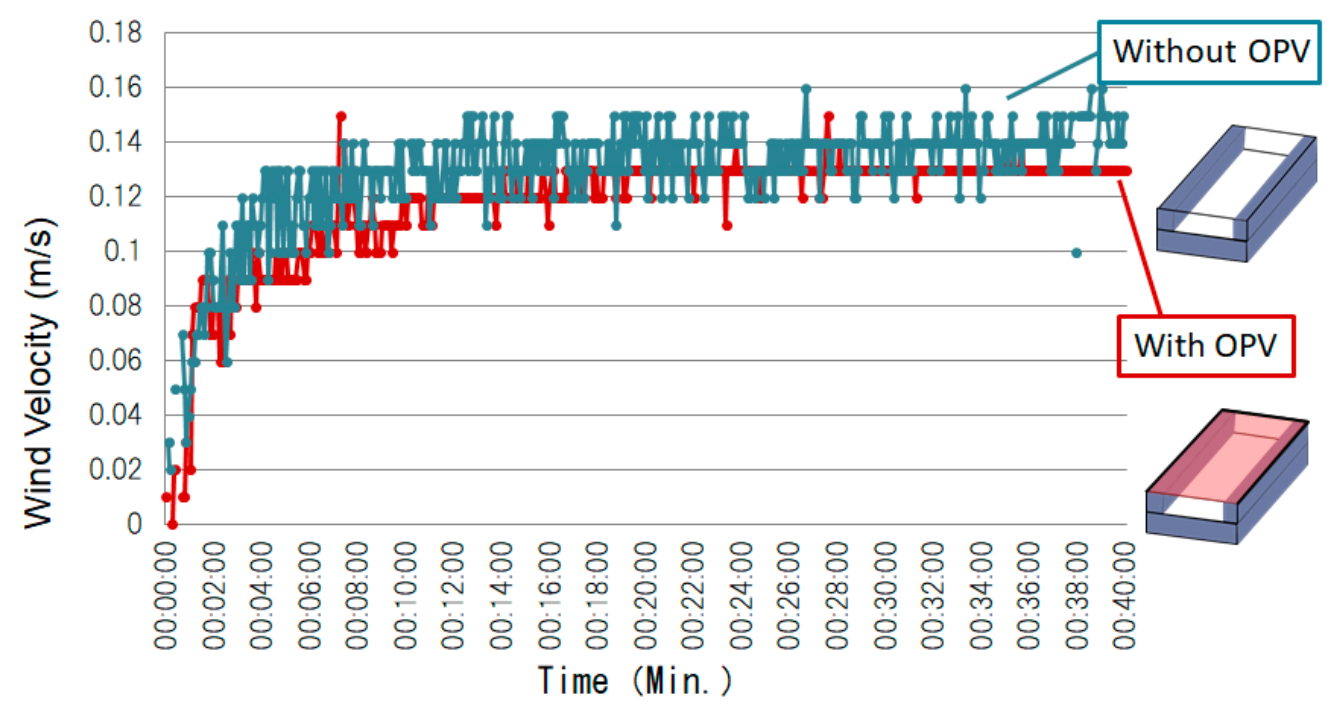

Figure 9. Velocity of generated wind in OPV-solar chimney with and with OPV sheet.

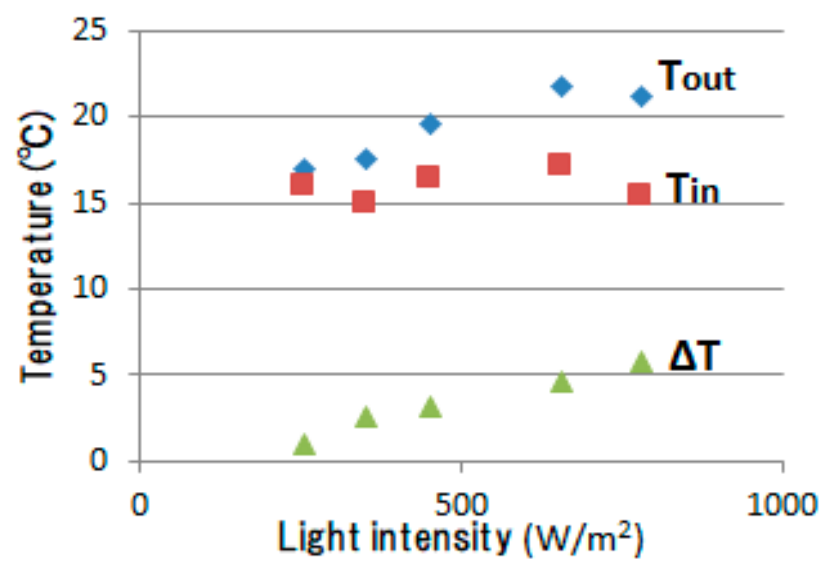

Figure 10. Inlet and outlet temperatures of OPV-solar chimney as a function of light intensity.

The values computed using Equation (2) are in good agreement with the experimental data for $\mathrm{Cd}=1.30$, as shown in Figure 11. The wind velocity at $\theta=10^{\circ}$ might have been suppressed by air stagnation due to the shallow pitch angle in the chimney. Nevertheless, the experimental data show good agreement with the computed values at higher pitch angles. According to Cho and Kimura [30], Cd in Equation (2) is inversely proportional to the square root of the air density. The $\mathrm{Cd}$ used here is about $18 \%$ smaller than that of the fitting value. This indicates that the evaluated data did not sufficiently satisfy the time duration to stabilize the thermal conditions affecting the equilibrium condition.

An OPV-solar chimney with a pitch angle greater than $30^{\circ}$ may be usable for irradiation at $655 \mathrm{~W} / \mathrm{m}^{2}$. We speculate that the friction resistance of the laminar air flow against the inside of the wall is reduced at higher pitch angles. 


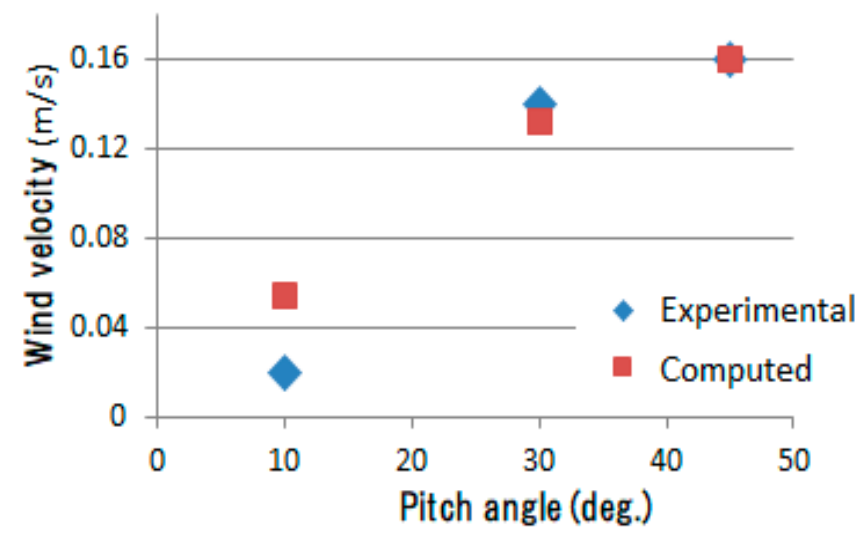

Figure 11. Velocity of generated wind in OPV-solar chimney at light intensity of $655 \mathrm{~W} / \mathrm{m}^{2}$ as a function of pitch angle.

Figure 12 shows temperature profiles in the chimney as a function of time. The highest temperature was observed for channel 3, which was at the top surface of the irradiated area. The temperature showed saturation after $12 \mathrm{~min}$ from the outset. Most temperature profiles of the top surface behaved in the same manner while the temperatures at the bottom rose more slowly. This temperature difference may cause air flow in the chimney due to migration of uplifting warm air.

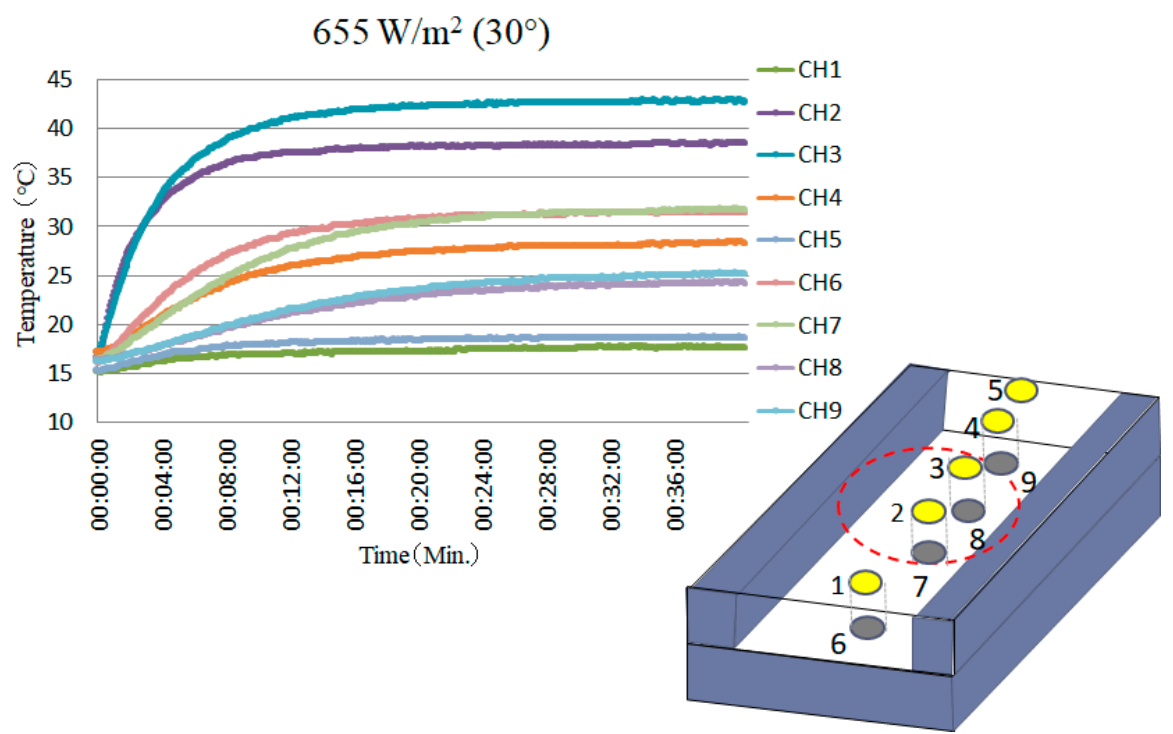

Figure 12. Temperature profiles in small-scale OPV-solar chimney as a function of time. Dashed circle indicates light-exposed area.

The amount of light irradiation on the OPV-solar chimney is another factor in how the chimney behaves under various intensities. Figure 9 shows the inlet and outlet temperatures along with the relative differences. The temperature difference is the greatest concern in terms of wind generation, and the figure shows that it increases linearly with light intensity.

Figure 13 shows the generated wind velocity as a function of light intensity. The velocity of the generated wind is proportional to the square root of the normalized temperature, as shown in Equation (1). The experimental data agrees well with the computed values for $\mathrm{Cd}$ is 1.30 . 


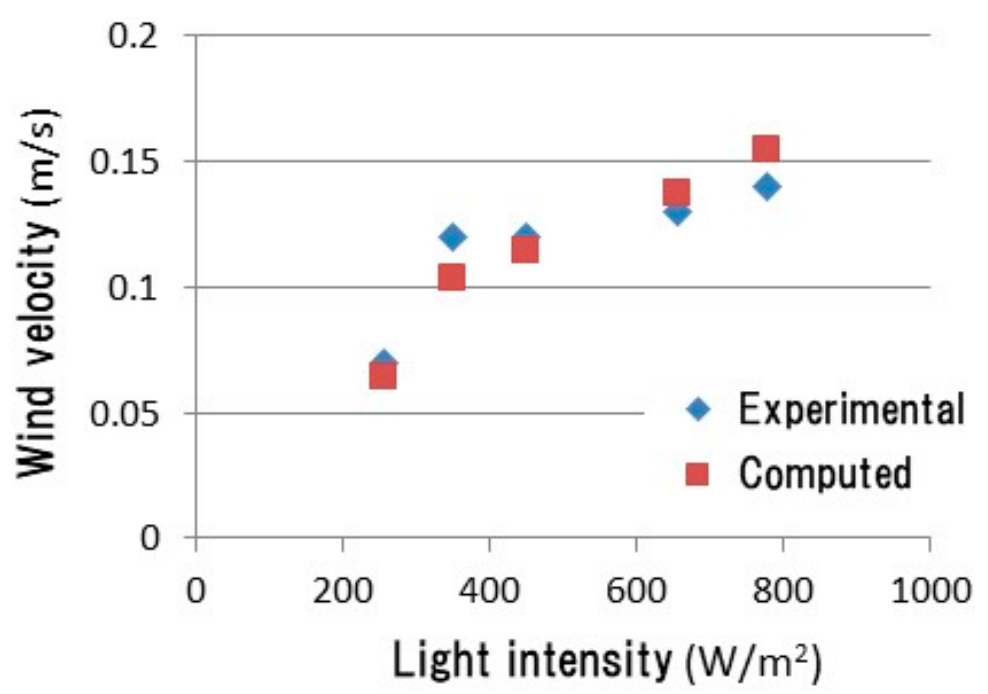

Figure 13. Velocity of generated wind in small-scale OPV-solar chimney as a function of light intensity.

A prototype large-scale OPV-solar chimney was used for evaluating the temperature distribution, wind velocity, and power generation. The experiment was carried out using a light intensity of $320 \mathrm{~W} / \mathrm{m}^{2}$ and a pitch angle of $60^{\circ}$. Figure 14 shows the temperature distribution as a function of time. The temperature profiles show that an initial increase in the OPV surface temperature for the large-scale chimney became slow compared to that for a small-scale chimney. The outlet wind air temperature for the large-scale chimney showed instability in the early stage. This indicates that air stagnation might continue until sufficient heat capacity is achieved. The size of the exposed area may also affect thermal dissipation along the periphery of light.

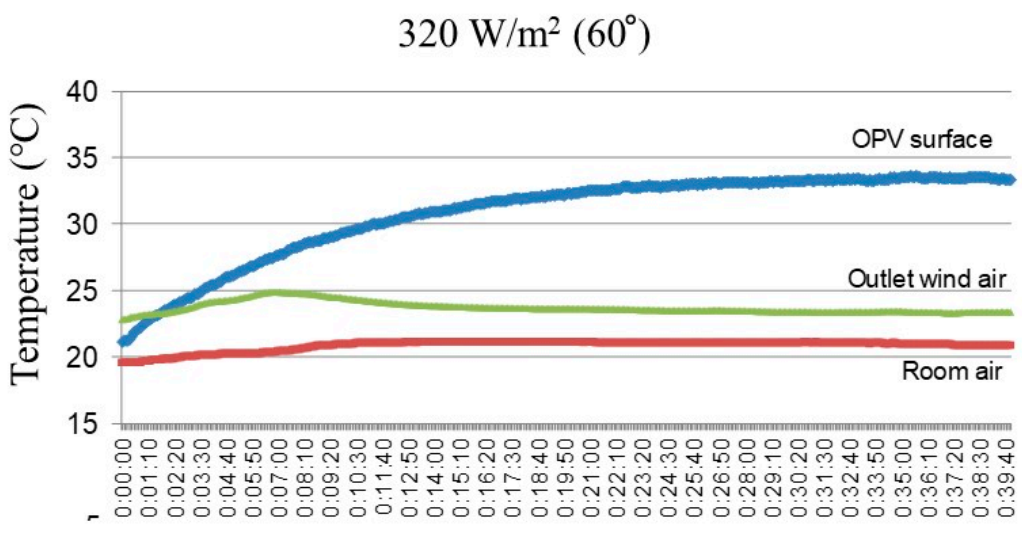

Time (Min.)

Figure 14. Temperature distribution in large-scale OPV-solar chimney as a function of time.

Figure 15 shows the velocity of the generated wind at the outlet opening of the large-scale OPV-solar chimney as a function of time. The wind velocity stabilized after about $1 \mathrm{~min}$. Thus, the wind velocity for a large-scale chimney can be obtained by extrapolating the results for a small-scale chimney. The wind velocity at a pitch angle of $60^{\circ}$ as estimated from the results shown in Figure 7 is about $0.2 \mathrm{~m} / \mathrm{s}$. This agrees well with the prediction. 


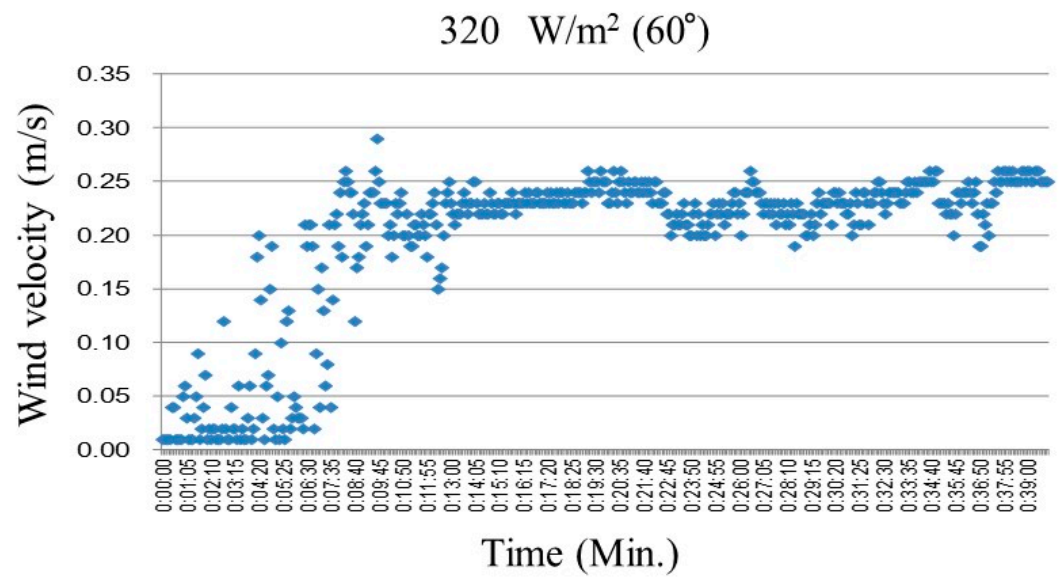

Figure 15. Generated wind velocity in large-scale OPV-solar chimney as a function of time.

Figure 16 shows the power generated by the OPV device at a light intensity of $320 \mathrm{~W} / \mathrm{m}^{2}$. In general, the power generated decreases as the temperature increase in solid-silicon photovoltaics. In contrast, the OPV device generated a constant power even when the temperature of the sheet increased. These results demonstrate the thermal stability of the OPV device in terms of power generation.

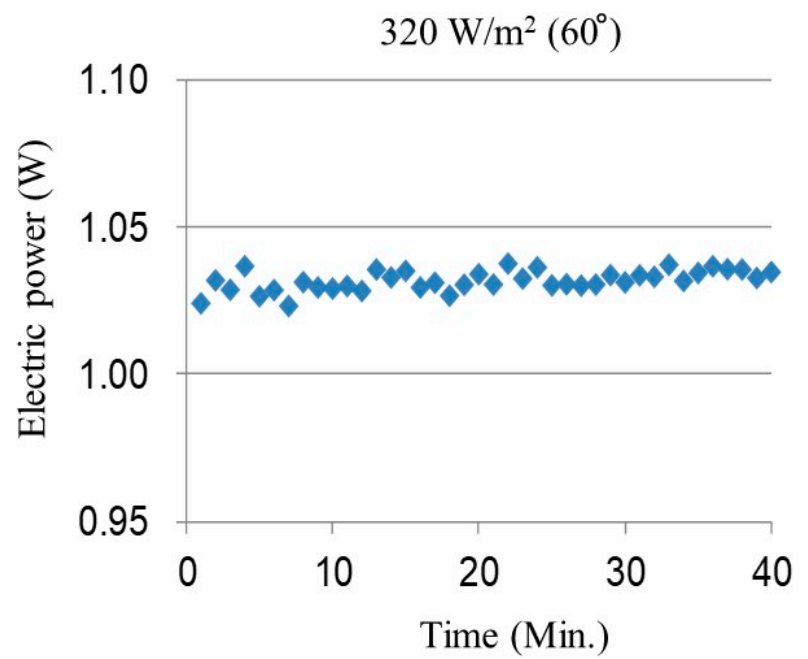

Figure 16. Electric power generated by large-scale OPV-solar chimney as a function of time.

We can conclude that solar power generation is compatible with heat absorption in the OPV-solar chimney.

\section{Conclusions}

The proposed energy-efficient building ventilation system achieved a wind velocity of $0.25 \mathrm{~m} / \mathrm{s}$ and electric power generation of about $1.03 \mathrm{~W}$ at an artificial light intensity of $320 \mathrm{~W} / \mathrm{m}^{2}$, which corresponds to cloudy weather. These results support the basic study of systems combining ventilation and power generation. The integration of solar chimney ventilation with OPV power generation could be a promising system for energy savings in the future. The proposed integration could contribute to the generation of sustainable and renewable energy. The energy-saving effect would be enhanced by applying this system to larger scale architectures and buildings. Future work includes developing a system suitable for a wide range of structures and evaluating its feasibility for industrial use. The practical use of this system requires that several issues such as production cost and 
performance be addressed. Furthermore, this system should be compared with other applications to determine the potential energy savings.

Author Contributions: K.H. was responsible to main body of this manuscript. A.M., H.H., and Y.S. were responsible to experimental part of it. K.M. and Y.N. supervised entire study. N.Y. was planning this study and responsible to OPV part of this manuscript.

Funding: This research received no external funding.

Conflicts of Interest: The authors declare no conflict of interest.

\section{References}

1. International Energy Agency. World Energy Outlook 2017; International Energy Agency: Paris, France, 2017.

2. Zeng, B.; Zhang, J.; Yang, X.; Wang, J.; Dong, J.; Zhang, Y. Integrated Planning for Transition to Low-Carbon Distribution System with Renewable Energy Generation and Demand Response. IEEE Trans. Power Syst. 2014, 29, 1153-1165. [CrossRef]

3. Erdin, O.; Paterakis, N.G.; Pappi, I.N.; Bakirtzis, A.G.; Catalao, J.P.S. A new perspective for sizing of distributed generation and energy storage for smart households under demand response. Appl. Energy 2015, 143, 26-37. [CrossRef]

4. Prasad, D.; Snow, M. Designing with Solar Power; Earthscan: London, UK, 2005.

5. Akata, A.M.E.A.; Njomo, D.; Agrawal, B. Assessment of Building Integrated Photovoltaic (BIPV) for sustainable energy performance in tropical regions of Cameroon. Renew. Sustain. Energy Rev. 2017, 80, 1138-1152. [CrossRef]

6. Shukla, A.K.; Sudhakar, K.; Baredar, P. Recent Advancement in BIPV product technologies: A review. Energy Build. 2017, 140, 188-195. [CrossRef]

7. Pomponi, F.; Piroozfar, P.A.E.; Southall, R.; Ashton, P.; Farr, E.R.P. Energy performance of double-skin façades in temperate climates: a systematic review and meta-analysis. Renew. Sustain. Energy Rev. 2016, 54, 1525-1536. [CrossRef]

8. Gracia, A.; Navarro, L.; Castell, A.; Cabeza, L.F. Energy performance of a ventilated double skin facade with PCM under different climates. Energy Build. 2015, 91, 37-42. [CrossRef]

9. Mateus, N.M.; Pinto, A.; da Graça, G.C. Validation of EnergyPlus thermal simulation of a double skin naturally and mechanically ventilated test cell. Energy Build. 2014, 75, 511-522. [CrossRef]

10. Imran, A.A.; Jalil, J.M.; Ahmed, S.T. Induced flow for ventilation and cooling by a solar chimney. Renew. Energy 2015, 78, 236-244. [CrossRef]

11. Khanal, R.; Lei, C. A numerical investigation of buoyancy induced turbulent air flow in an inclined passive wall solar chimney for natural ventilation. Energy Build. 2015, 93, 217-226. [CrossRef]

12. Peng, J.; Curcija, D.C.; Lu, L.; Selkowitz, S.E.; Yang, H.; Mitchell, R. Developing a method and simulation model for evaluating the overall energy performance of a ventilated semi-transparent photovoltaic double-skin facade. Prog. Photovolt. 2015, 24, 781-799. [CrossRef]

13. Agathokleous, R.A.; Kalogirou, S.A. Double skin facades (DSF) and building integrated photovoltaics (BIPV): A review of configurations and heat transfer characteristics. Renew. Energy 2016, 89, 743-756. [CrossRef]

14. Wang, M.; Peng, J.; Li, N.; Yang, H.; Wang, C.; Li, X.; Lu, T. Comparison of energy performance between PV double skin facades and PV insulating glass units. Appl. Energy 2017, 194, 148-160. [CrossRef]

15. Lai, C.-M.; Hokoi, S. Solar façades: A review. Build. Environ. 2015, 91, 152-165. [CrossRef]

16. Klimeš, L.; Charvát, P.; Hejčík, J. Comparison of the Energy Conversion Efficiency of a Solar Chimney and a Solar PV-Powered Fan for Ventilation Applications. Energies 2018, 11, 912. [CrossRef]

17. Peng, J.; Curcija, D.C.; Lu, L.; Selkowitz, S.E.; Yang, H.; Zhang, W. Numerical investigation of the energy saving potential of a semi-transparent photovoltaic double-skin facade in a cool-summer Mediterranean climate. Appl. Energy 2016, 165, 345-356. [CrossRef]

18. Bloem, J.J.; Lodi, C.; Cipriano, J.; Chemisana, D. An outdoor Test Reference Environment for double skin applications of Building Integrated Photovoltaic Systems. Energy Build. 2012, 50, 63-73. [CrossRef]

19. Charron, R.; Athienitis, A.K. Optimization of the performance of double-façades with integrated photovoltaic panels and motorized blinds. Sol. Energy 2006, 80, 482-491. [CrossRef] 
20. Yoon, S.; Tak, S.; Kim, J.; Jun, Y.; Kang, K.; Park, J. Application of transparent dye-sensitized solar cells to building integrated photovoltaic systems. Build. Environ. 2011, 46, 1899-1904. [CrossRef]

21. Olivieri, L.; Caamano, E.; Olivieri, F.; Neila, J. Integral energy performance characterization of semi-transparent photovoltaic elements for building integration under real operation conditions. Energy Build. 2014, 68, 280-291. [CrossRef]

22. Peng, J.; Lin, L.; Yang, H. Influences of ambient air speed and internal heat load on the performance of solar chimney in the tropics. Sol. Energy 2014, 102, 116-125.

23. Tan, A.Y.K.; Wong, N.H. An experimental study of the thermal performance of a novel photovoltaic double-skin facade in Hong Kong. Sol. Energy 2013, 97, 293-304.

24. Lee, J.W.; Park, J.; Jung, H.-J. A feasibility study on a building's window system based on dye-sensitized solar cells. Energy Build. 2014, 81, 38-47. [CrossRef]

25. Chen, C.-C.; Dou, L.; Zhu, R.; Chung, C.-H.; Song, T.-B.; Zheng, Y.B.; Hawks, S.; Li, G.; Weiss, P.S.; Yang, Y. Visibly Transparent Polymer Solar Cells Produced by Solution Processing. ACS Nano 2012, 6, 7185-7190. [CrossRef] [PubMed]

26. Lu, H.; Lin, J.; Wu, N.; Nie, S.; Luo, Q.; Ma, C.-Q.; Cui, Z. Inkjet printed silver nanowire network as top electrode for semi-transparent organic photovoltaic devices. Appl. Phys. Lett. 2015, 106, 093302. [CrossRef]

27. Kapsis, K.; Athienitis, A.K. A study of the potential benefits of semi-transparent photovoltaics in commercial buildings. Sol. Energy 2015, 115, 120-132. [CrossRef]

28. Yoshimoto, N.; Suenaga, Y.; Hidaka, K.; Mitsuji, K.; Nagai, Y. Perimeter Energy System applied for Transparent Organic Photovoltaics. In Proceedings of the 11th International Symposium on Architectural Interchanges in Asia (ISAIA2016), Sendai, Japan, 20-23 September 2016.

29. Suenaga, Y.; Yoshimoto, N.; Hidaka, K.; Mitsuji, K.; Nagai, Y. Solar Chimney System embedded Transparent Organic Photovoltaics Part 1: Basic Study of Natural Ventilation Behavior under Irradiation Condition with Solar Simulator. In Proceedings of AIJ Tohoku Chapter Architectural Design Meeting; Architectural Institute of Japan: Tohoku, Japan, 2010; p. A-12.

30. Cho, S.W.; Kimura, K.-I. Experimental Study on The Performance Prediction of Natural Ventilation System with Solar Chimney. J. Soc. Heat. Air-Cond. Sanit. Eng. Jpn. 2001, 81, 11-19.

(C) 2018 by the authors. Licensee MDPI, Basel, Switzerland. This article is an open access article distributed under the terms and conditions of the Creative Commons Attribution (CC BY) license (http:/ / creativecommons.org/licenses/by/4.0/). 